\title{
Factors Affecting Ginger Production in Sunsari District, Nepal
}

\author{
Soni Ghimire ${ }^{1 *}$, Devendra Prasad Chalise ${ }^{1}$, Jyoti Neupane ${ }^{\mathbf{1}}$ and Kedar Devkota $^{2}$ \\ ${ }^{1}$ Department of Agriculture, Agriculture and Forestry University, Rampur, Nepal \\ ${ }^{2}$ Assistant Professor, Department of Agricultural Economics and Agri-business Management, Agriculture and Forestry University, Rampur, \\ Chitwan, Nepal \\ *Corresponding Author: Soni Ghimire, Department of Agriculture, Agriculture and Forestry University, Rampur, Nepal.
}

Received: September 16, 2019; Published: October 30, 2019

DOI: 10.31080/ASAG.2019.03.0705

\begin{abstract}
A study was conducted in Bishnupaduka and Panchkanya of Sunsari district from February to May, 2019 with the objective to study factors affecting ginger production. Purposive selection of the site was done. For the study, eighty ginger growers were selected using simple random sampling method. Well-designed questionnaire was administered to the growers for primary data collection after pretesting it. Secondary data was obtained through journals, research articles, publications and reports. Key Informant Interview with progressive farmers, farmer leaders, manager of private farms and local extension workers was conducted along with questionnaire survey. The obtained data was analyzed using computer software packages like: MS Excel and SPSS. Indexing technique was used for qualitative data to rank each problem. Correlation coefficient tested the strength of relationship between various dependent and independent variables. The study showed that educational status, time of planting, planting distance, types of farming and training had positive and significant relationship with the level of production while seed treatment and crop rotation had positive but highly significant relationship with the level of production, each having Chi-square value of 18.42. Similarly, seed quantity, manure quantity, frequency of weeding, labor cost, family size, land size under ginger cultivation and experience on ginger farming were found to have positive and significant correlation with the level of production with Pearson correlation coefficient of $0.22,0.271$, $0.203,0.208,0.22,0.253$ and 0.26 respectively while the age of the respondents was found to be negatively correlated with the level of production with the Pearson correlation coefficient as -0.25 . Similarly, price was also found to be a determining factor influencing the level of production as well. Further, the prevalence of rhizome rot disease was found to be the bottleneck in ginger cultivation. Also, obtaining quality planting materials, proper irrigation facilities, lack of quality inputs, labor crisis were identified as other major problems during ginger production.

Keywords: Ginger; Production; Rhizome Rot
\end{abstract}

\section{Introduction}

Ginger is one of the promising high value spice crops having a large production and export potential for Nepal [1]. Ginger (Zingiber officinale) is a monocotyledonous, herbaceous tropical plant belonging to the family Zingiberaceae [2]. It is a flowering plant whose rhizome is widely used as spice either in its fresh form or dry form or used for various other medicinal purposes [3]. It is used in the preparation of pickles, candy, squash, powder, sutho (dried ginger), and beverages. Dried form of ginger contains 15\% aromatic oil, $6 \%$ oleoresin while the fresh form contains $12.3 \%$ carbohydrate, $2.3 \%$ protein and $0.9 \%$ fats and some amount of vitamins and minerals [4]. It also helps in preventing nausea, asthma, cancer, migraine, constipation, cold, blanching, cholesterol and blood pressure.

Ginger farming is the main source of income for the peasants of mid-hills in Nepal who derive their living from fragmented plots of land [5]. It is being grown in commercial scale due its climacteric suitability across the whole east-west length along the Siwalik and mid hill ranges extending up to the altitudes of $1500 \mathrm{~m}$ [6]. Farmers generally cultivate two landraces of ginger, Nase and Bose. Ginger Research Program (GRP), Salyan has released two varieties of ginger, Kapurkot Aduwa-1 in 2001 and Kapurkot Aduwa-2 in 2016 [7].

Ginger plays an important role in agrarian and industrial development of the country like ours [8]. As defined by the government of Nepal, ginger is one of the 12 priority export products of Nepal Trade Integration Strategy [9]. Nepal is $4^{\text {th }}$ in worldwide ginger production after India, China and Nigeria and contributes about 9.19\% to the world's production [10]. Nepal lies in $5^{\text {th }}$ position in terms of total export volume of ginger [11].

The total area under ginger cultivation in Nepal was 21,869 ha with the productivity of $12.43 \mathrm{Mt} / \mathrm{ha}$ whereas area under ginger cultivation in Sunsari district was 450 ha producing 4235 Mt of ginger with productivity of $9.41 \mathrm{Mt} / \mathrm{ha}$. Thus, this study was carried out to attain the following objectives:

1. To determine various factors affecting ginger production and find their relationship with the production 
2. To study the major constraints faced by ginger growers during production

3. To identify various factors that motivate farmers towards ginger production.

\section{Materials and Methods}

Study site

The highly potential areas, Bishnupaduka (Dharan-20) and Panchakanya (Dharan-6) of Sunsari district of Province number 1 which lies in the Eastern Terai of Nepal was purposively selected for the study as there are remarkable numbers of ginger growers, remarkable area coverage by ginger, good production of ginger and better access to road facility in this district.

\section{Selection of ginger growers}

A total of 80 respondents were selected, 40 ginger growers from each Panchakanya and Bishnupaduka by random sampling technique to draw a representative sample.

\section{Survey design and data collection}

Interview schedule was prepared for collecting primary information from ginger growers. Pre-testing was done to test the validity and effectiveness of the interview schedule. Two FGDs were carried out to cross check the information obtained through interview schedule. An in-depth interview was conducted with Senior Agriculture Officer of Zone Implementation Unit, president of Zone Operation Committee, progressive farmers, farmer leaders, manager of private farms and local extension workers to get aid to set close ended questions in interview schedule.

\section{Methods and techniques of data analysis}

Quantitative and qualitative data obtained from survey were coded, entered and analysed by using SPSS and Ms-Excel software. Data was analyzed by using statistical tools like descriptive statistics, frequency distribution, trend analysis, mean comparison, etc. Chi-square test $(\chi 2)$ was used to study the association between two categorical variables while correlation was used to show the relationship between two continuous variables. Further, indexing technique was used to rank various problems that the farmers faced during production level and various motivational factors that motivated them towards ginger farming.

Chi-square was calculated by using the formula,

$$
\chi^{2}=\sum \frac{\left(O_{i j}-E_{i j}\right)^{2}}{E_{i j}}
$$

where,

Oij = observed frequency of each ijth term

Eij $=$ expected frequency of ijth term

$$
\begin{aligned}
& i=1,2,3, \ldots \ldots . ., r \\
& j=1,2,3, \ldots \ldots . ., k \\
& d f=(c-1)(r-1)
\end{aligned}
$$

where,

$\mathrm{c}=$ number of columns

$r=$ number of rows
This was tested at 0.05 and 0.01 level of probability for different degree of freedom.

Indexing of importance was calculated by using the formula,

$$
\begin{aligned}
& \mathrm{I}_{\mathrm{imp}} / \mathrm{I}_{\text {prob }}=\sum\left(\mathrm{S}_{\mathrm{i}} \mathrm{F}_{\mathrm{i}} / \mathrm{N}\right) \\
& \mathrm{I}_{\text {imp }} / \mathrm{I}_{\text {prob }}=\text { index of importance } / \\
& \sum=\text { Summation } \\
& \mathrm{S}_{\mathrm{i}}=\text { Scale value of } \mathrm{i}^{\text {th }} \text { intensity } \\
& \mathrm{F}_{\mathrm{i}}=\text { Frequency of } \mathrm{i}^{\text {th }} \text { response } \\
& \mathrm{N}=\text { Total no. of respondent }
\end{aligned}
$$$$
\mathrm{I}_{\mathrm{imp}} / \mathrm{I}_{\mathrm{prob}}=\text { index of importance/ index value for intensity of problem }
$$

\section{Results and Discussion} Production level of ginger

The average ginger production per household was calculated and it was found to be $393 \mathrm{~kg}$ per kattha. Based on this, ginger was categorized into two production levels; low production (ginger yield less than $393 \mathrm{~kg}$ ) and high production level (ginger yield more than $393 \mathrm{~kg}$ per kattha).

\begin{tabular}{|l|c|}
\hline \multicolumn{1}{|c|}{ Production level of ginger } & Frequency \\
\hline Low & $34(42.5)$ \\
\hline High & $46(57.5)$ \\
\hline Total & $80(100)$ \\
\hline
\end{tabular}

Table 1: Production level of ginger in the study area. Note: Figures in parenthesis indicate percentage Source: Field survey, 2019

\section{Chi-Square analysis between factors and ginger production}

Results of Chi-square test revealed that educational status had positive and strong relationship with the level of production at $5 \%$ level of significance. Higher the educational level, higher will be the level of production. Level of production was also found to be positive and strongly dependent on seed treatment at $1 \%$ level of significance. Seed treatment improved the level of production because it prevented the spread of rhizome rot pathogens during growth.

Similarly, level of production was found to be positive and dependent on time of panting at $10 \%$ level of significance. Similar result was observed where farmers believed early planted ginger escaped hailstorms and resulted in high yields [12]. Also, the study showed that there was significant relationship between the level of production and planting distance and types of farming at $10 \%$ level of significance. The result of planting distance was in agreement with the findings of [13] which stated that the inter row spacing of $40 \mathrm{~cm}$ gave higher mean fresh rhizome yield per plant which was not statistically different from $30 \mathrm{~cm}$ spacing.

Further, frequency of irrigation and cropping system were found to have non-significant relationship with the level of production while crop rotation and types of manure used were found to have positive and significant relationship at $1 \%$ level of significance. 
Training and types of extension services received by the farmers were found to be positively significant at $10 \%$ with level of production.
Correlation analysis between factors and production

Correlation analysis revealed that the variables viz. family size, land size under ginger cultivation, experience on ginger farming,

\begin{tabular}{|c|c|c|c|c|c|}
\hline \multirow{2}{*}{ Factors } & \multicolumn{3}{|c|}{ Production level } & \multirow{2}{*}{$\chi^{2}$ Cal } & \multirow{2}{*}{ P-value } \\
\hline & Low & High & Total & & \\
\hline \multicolumn{6}{|l|}{ Educational status } \\
\hline Illiterate & $15(44.1)$ & $7(15.2)$ & $22(27.5)$ & \multirow[t]{5}{*}{$10.77^{* *}$} & \multirow[t]{4}{*}{0.029} \\
\hline Primary & $10(29.4)$ & $20(43.5)$ & $30(37.5)$ & & \\
\hline Secondary & $9(26.5)$ & $14(30.4)$ & $23(28.7)$ & & \\
\hline Higher secondary & $0(0)$ & $3(6.5)$ & $3(3.8)$ & & \\
\hline University & $0(0)$ & $2(4.3)$ & $2(2.5)$ & & \\
\hline \multicolumn{6}{|l|}{ Seed treatment } \\
\hline Yes & $0(0)$ & $19(41.3)$ & $19(23.8)$ & $18.42^{* * *}$ & 0.000 \\
\hline No & $34(100)$ & $27(58.7)$ & $61(76 . .3)$ & & \\
\hline \multicolumn{6}{|l|}{ Time of planting } \\
\hline Falgun & $5(14.7)$ & $17(37)$ & $22(27.5)$ & $4.95^{* *}$ & 0.044 \\
\hline Chaitra & $21(61.8)$ & $22(47.8)$ & $43(53.8)$ & & \\
\hline Baisakh & $8(23.5)$ & $7(15.2)$ & $15(18.8)$ & & \\
\hline \multicolumn{6}{|l|}{ Planting distance } \\
\hline $25 * 25$ & $2(5.9)$ & $5(10.9)$ & $7(8.8)$ & 5.71* & 0.058 \\
\hline $30 * 30$ & $20(58.8)$ & $35(76.1)$ & $55(68.8)$ & & \\
\hline $40 * 40$ & $12(35.3)$ & $6(13)$ & $18(22.5)$ & & \\
\hline \multicolumn{6}{|l|}{ Types of farming } \\
\hline Rain fed & $23(67.6)$ & $39(84.8)$ & $62(77.5)$ & $3.23 *$ & 0.062 \\
\hline Irrigated & $11(32.4)$ & $7(15.2)$ & $18(22.5)$ & & \\
\hline \multicolumn{6}{|l|}{ Frequency of irrigation } \\
\hline Frequent & $1(2.9)$ & $6(13)$ & $7(8.8)$ & $3.72^{\mathrm{ns}}$ & 0.293 \\
\hline Often & $5(14.7)$ & $3(6.5)$ & $8(10)$ & & \\
\hline Rare & $1(2.9)$ & $2(4.3)$ & $3(3.8)$ & & \\
\hline Never & $27(79.4)$ & $35(76.1)$ & $62(77.5)$ & & \\
\hline \multicolumn{6}{|l|}{ Cropping system } \\
\hline Sole cropping & $25(73.5)$ & $32(69.6)$ & $57(71.3)$ & $1.150^{\mathrm{ns}}$ & 0.69 \\
\hline Mixed cropping & $9(26.5)$ & $14(30.4)$ & $23(28.7)$ & & \\
\hline \multicolumn{6}{|l|}{ Crop rotation } \\
\hline Yes & $0(0)$ & $19(41.3)$ & $19(20.7)$ & $18.42^{* * *}$ & 0.00 \\
\hline No & $34(100)$ & $27(58.7)$ & $61(79.3)$ & & \\
\hline \multicolumn{6}{|l|}{ Types of manure used } \\
\hline Organic & $32(94.1)$ & $40(87)$ & $72(90)$ & $18.42^{* * *}$ & 0.00 \\
\hline Organic + Chemical & $2(5.9)$ & $6(13)$ & $8(10)$ & & \\
\hline \multicolumn{6}{|l|}{ Training } \\
\hline Yes & $21(61.8)$ & $37(80.4)$ & $58(72.5)$ & $3.42^{*}$ & 0.064 \\
\hline No & $13(38.2)$ & $9(19.6)$ & $22(27.5)$ & & \\
\hline \multicolumn{6}{|c|}{ Types of extension services } \\
\hline Technical information & $10(29.4)$ & $13(28.3)$ & $23(28.7)$ & $5.18^{*}$ & 0.075 \\
\hline Marketing information & $4(11.8)$ & $15(32.6)$ & $19(23.8)$ & & \\
\hline Both & $20(58.8)$ & $18(39.1)$ & $38(47.5)$ & & \\
\hline
\end{tabular}

Table 2: Distribution of respondents according to different factors and level of production.

Note: Figures in parenthesis indicates percentage; ${ }^{* * *}$ and ${ }^{* * *}$ indicate $10 \%, 5 \%$ and $1 \%$ level of significance and ${ }^{\text {ns }}$ indicates non-significant. Source: Field survey, 2019

seed quantity and manure quantity had positive and significant relationship with the level of production at $5 \%$ level of significance. The result of experience on ginger farming was in accordance with the result obtained from [14] who had observed that increased farming experience was positively correlated with adoption of technologies thereby contributing an increase in productivity of ginger.

Similarly, frequency of weeding and labor cost from land preparation to harvesting had positive and strong significant relationship with the level of production at $1 \%$ level of significance while age 
was found to be negatively significant with level of production of ginger. The result of weeding was in accordance with the result obtained from [15], which reported that hand weeding twice at 30 DAP and 60 DAP recorded significantly higher fresh rhizome yield.

\begin{tabular}{|l|c|c|c|}
\hline \multicolumn{1}{|c|}{ Factors } & $\begin{array}{c}\text { Pearson } \\
\text { correlation }\end{array}$ & $\begin{array}{c}\text { Sig. } \\
\text { (2 tailed) 'p' }\end{array}$ & $\begin{array}{c}\text { Sample } \\
\text { Size 'N' }\end{array}$ \\
\hline Family size in number & $0.22^{* *}$ & 0.049 & 80 \\
\hline Age & $-0.25^{* *}$ & 0.026 & 80 \\
\hline $\begin{array}{l}\text { Experience on ginger } \\
\text { farming }\end{array}$ & $0.26^{* *}$ & 0.019 & 80 \\
\hline $\begin{array}{l}\text { Land size under } \\
\text { ginger cultivation }\end{array}$ & $0.253^{* *}$ & 0.024 & 80 \\
\hline Seed quantity & $0.22^{* *}$ & 0.048 & 80 \\
\hline Manure quantity & $0.271^{* *}$ & 0.015 & 80 \\
\hline Frequency of weeding & $0.203^{*}$ & 0.071 & 80 \\
\hline $\begin{array}{l}\text { Labor cost from land } \\
\text { preparation to har- } \\
\text { vesting }\end{array}$ & $0.208^{*}$ & 0.064 & 80 \\
\hline
\end{tabular}

Table 3: Correlation analysis between factors and production.

Note: ${ }^{* *}$ and ${ }^{*}$ indicates $5 \%$ and $1 \%$ level of significance

\section{Problems during production}

Amid several problems faced by the total population surveyed in the study area during production level, diseases and insects problem was reported as the most severe one with the index value (0.90). Most frequently seen diseases included rhizome rot and leaf spot and insects included rhizome-fly and white grub. All the ranked problems had direct effect on the quality production of ginger.

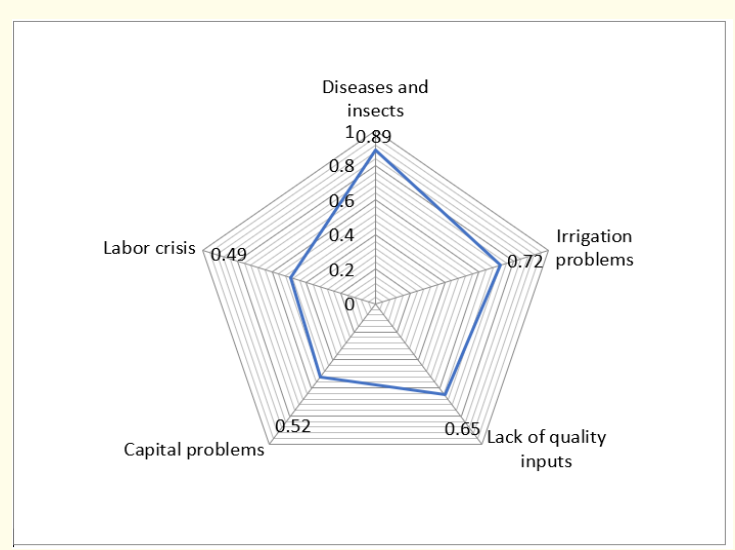

Figure 1: Diagram representing the problems faced by ginger growers during production.

\section{Motivating factors for ginger production}

The respondents reckoned that their tradition of offering ginger during religious activities was the most important motivational factors for their involvement in ginger farming with index value (0.84). It was followed by profitability (0.79) then, government prioritization and support to the commodity (0.69) such as provision of trainings, input subsidy and technology dissemination followed by escape from monkeys $(0.67)$ and finally the agro-climatic suitability (0.54) of the study area for ginger farming.

\begin{tabular}{|l|c|c|c|c|c|c|c|c|}
\hline \multirow{2}{*}{ Factors } & \multicolumn{5}{|c|}{ Scores assigned } & Weight- & Index & Rank \\
\cline { 2 - 8 } & $\mathbf{1}$ & $\mathbf{0 . 8}$ & $\mathbf{0 . 6}$ & $\mathbf{0 . 4}$ & $\mathbf{0 . 2}$ & $\mathbf{\text { Ige }}$ & In \\
\hline $\begin{array}{l}\text { Following the } \\
\text { tradition }\end{array}$ & 39 & 22 & 14 & 5 & & 67 & 0.84 & I \\
\hline $\begin{array}{l}\text { Benefits and po- } \\
\text { tential economic } \\
\text { returns }\end{array}$ & 31 & 23 & 7 & 13 & 6 & 60 & 0.75 & II \\
\hline $\begin{array}{l}\text { Marginal land } \\
\text { utilization and } \\
\text { escape from } \\
\text { monkeys }\end{array}$ & 29 & 19 & 16 & 8 & 8 & 58.6 & 0.73 & III \\
\hline $\begin{array}{l}\text { Government } \\
\text { prioritization and } \\
\text { support to the } \\
\text { Commodity }\end{array}$ & 22 & 16 & 15 & 14 & 13 & 52 & 0.65 & IV \\
\hline $\begin{array}{l}\text { Agro-climatic } \\
\text { suitability }\end{array}$ & 15 & 14 & 22 & 21 & 8 & 49.4 & 0.61 & V \\
\hline
\end{tabular}

Table 4: Ranking of motivating factors for ginger production.

\section{Price trend of ginger}

The market condition of ginger is not steady. This is mainly due to the dependency on Indian market. Farmers received a price of NRs. 70/kg in the year 2014/15 which dropped to NRs. 60/kg for the next two years. This was due to the restriction imposed by India on the export of ginger raising issues related to phytosanitation and implementation of Goods and Services Tax (GST). This scenario dwindled the ginger production this year as many farmers abandoned this farming as this profession involved much risk. Out of 80 respondents surveyed, only 16 respondents showed increasing trend of ginger cultivation while 40 showed decreasing trend and only 24 respondents were found to be constant in ginger cultivation. The situation was just opposite at present where the price rose rapidly reaching up to NRs. $120 / \mathrm{kg}$ thereby, encouraging many farmers towards this farming again.

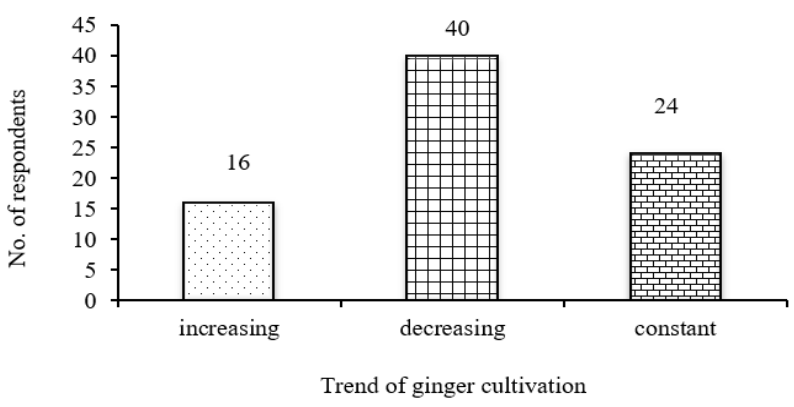

Figure 2: Bar diagram representing trends of ginger cultivation in Sunsari district in 2019.

Source: Field survey, 2019.

Motivation from satisfaction obtained from this year's price and yield to cultivate next year

This year, farmers received a price of around NRs.120/kg of ginger which was the highest over the decade. The price reached to the peak where the farmers had never expected that it would reach, not especially after last year's worst scenario when farmers were even not able to get NRs. $20 / \mathrm{kg}$ of ginger. This year's price was $500 \%$ more than last year's price. Cent percent of the respondents 
were satisfied with the price they received this year and amid them, $63.75 \%$ respondents were highly satisfied with the price.

Unfortunately, farmer's field this year was heavily infested with rhizome rot fungus which reduced the ginger yield to a great extent. Altogether 40 respondent's field was seriously affected. Amid 40, 23 were unsatisfied and 17 were strongly unsatisfied from their yield. It was found that only 16 respondents were highly satisfied and remaining 24 were just satisfied from the yield. The fungus demotivated farmers to a large extent and some farmers even reached to the point of abandoning this farming and seek another suitable occupation to sustain their livelihood. The bar graph below depicts the level of satisfaction of the farmers from the yield and price of ginger this year.

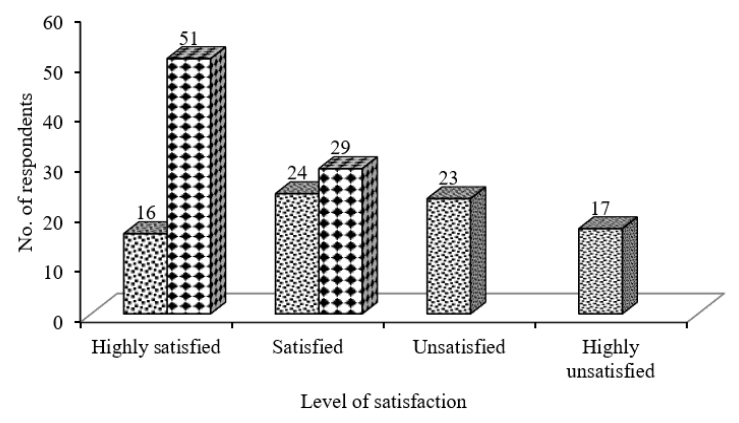

Figure 3: Bar diagram representing the level of satisfaction from yield and price of 2019.

Source: Field survey, 2019.

The infestation of rhizome rot in farmer's field, this year highly demotivated farmers to grow ginger next year. Out of 80 respondents, $69.1 \%$ were demotivated towards ginger production next year while this year's hiking of price motivated all ginger growing farmers towards the ginger production next year. Thus, price and production level of ginger, this year would directly affect the production of next year.

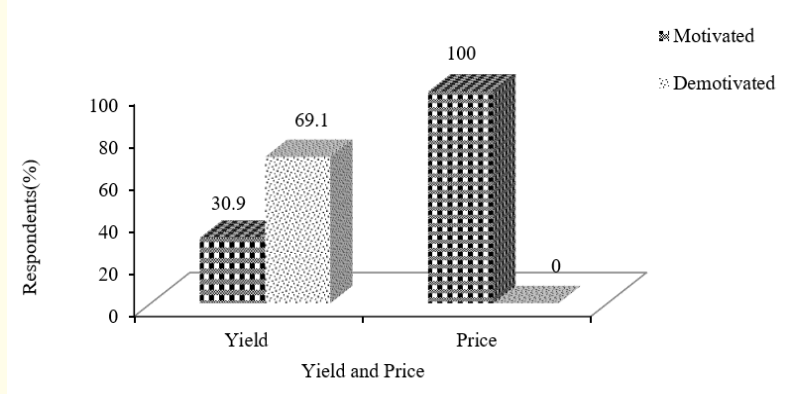

Figure 4: Bar diagram representing motivation from yield and price of 2019 to cultivate ginger in 2020.

Source: Field survey, 2019.

\section{Conclusion}

The research study concluded that though large number of farmers was found to be involved in ginger farming in the study area and though they were found to be aware about its impor- tance, majority of them were not satisfied from its production. They stated that prevalence of diseases, lack of quality seed rhizomes, lack of marketing facilities and improper irrigation facilities were the main hurdle faced by them during its production.

The results of the study further revealed that though the majority of the population surveyed, were literate, the level of awareness among them about the quality seed rhizomes and measures to control diseases was very low which showed that there was a weak linkage between researchers and ginger growers.

Hence, the findings of this study suggested in strengthening training programs related to ginger production and marketing, disease and insect management, proper arrangement of irrigation and transportation facilities, availability of quality seed rhizomes on time for increasing the production and productivity of ginger in Sunsari district of Nepal.

\section{Acknowledgments}

Authors would like to thank Assistant Professor, Kedar Devkota, Ph.D. and Prime Minister Agriculture Modernization Project-Ginger/Turmeric Zone, Sunsari, Nepal for their financial support and help during the research period.

\section{Bibliography}

1. ITC. Export Potential Assessment in Nepal. International Trade Centre (2007).

2. Joy PP. "Zingiberaceous Medicinal and Aromatic Plants" (1998).

3. Ali J and Rani P. "Effect of Drying on Ginger Paste and Optimization of Evaluated Quality Parameters of Dried Ginger Paste". International Journal of Food, Agriculture and Veterinary Sciences (2015).

4. Bhatt B. "Production and Marketing Management of Ginger". In Uttarakannda. M.Sc. Thesis, University of Agricultural Sciences, Dharwad (2011).

5. ANSAB. Ginger Value Chain Analysis Report Final. Asian Network for Sustainable Agriculture and Bioresources (2011).

6. Vancura L and Peneva T. "Opportunities for Nepalese Ginger and Derivative Products in Dubai Opportunities for Nepalese Ginger and Derivative Products in Dubai". A Report for Samarth-Nepal (2014).

7. AICC. Krishi Diary. Government of Nepal, Agribusiness Promotion and Statistics Division, Kathmandu, Nepal (2018).

8. GRP. Technical annual Report-2016/17. Kapurkot, Salyan, Nepal. Ginger Research Program, NARC 74 (2017).

9. Zoder LS. Ginger sector in Nepal. giz (2015).

10. FAOSTAT (2017).

11. FAOSTAT (2016). 
12. Ilyas., et al. "Growth, Yield and Quality of Ginger Produce Through Early Senescence". Journal of Applied Science and Technology (2016).

13. Woelore W. "Effects of Sett Size and Spacing on the Growth and Yield of Ginger (Zingiber officinale Rosc.) at Areka, Wolaita, Southern". Journal of Natural Sciences (2016).

14. Danladi Ezra MA. "Socio-economic Assessment of Ginger Production in Jaba Local Government Area of Kaduna State, Nigeria". Asian Journal of Agricultural Extension, Economics and Sociology (2017).

15. Sah D., et al. "Weed Management in Ginger (Zingiber officinale Roscoe) through Integrated Approaches". International Journal of Current Microbiology and Applied Sciences 6 (2017): 1839-1845.

\section{Volume 3 Issue 11 November 2019}

(C) All rights are reserved by Soni Ghimire., et al. 